\title{
Taking the "Human" Out of Human Rights
}

\author{
JOHN HARRIS
}

Human rights are universally acknowledged to be important, although they are, of course, by no means universally respected. This universality has helped to combat racism and sexism and other arbitrary and vicious forms of discrimination. Unfortunately, as we shall see, the universality of human rights is both too universal and not universal enough. ${ }^{1}$ It is time to take the "human" out of human rights. ${ }^{2}$ Indeed, it is very probable that in the future there will be no more humans as we know them now, because the further evolution of our species, either Darwinian or more likely determined by human choices, ${ }^{3}$ will, we must hope, result in the emergence of new sorts of beings better able to cope with the intellectual and physical challenges of the future. One example of the ways in which this is already happening is the sorts of cognitive enhancement that are already coming on stream. ${ }^{4}$ Another is signaled by stem cell research and the birth of regenerative medicine.

Human rights are one of the most important and universally accepted ideas both in moral and political philosophy and in contemporary jurisprudence. Although appeals to human rights are by no means unproblematic, where there is agreement or jurisprudential support for the existence of particular human rights, this fact becomes a powerful tool for the protection of such rights and for the remedies that such protection affords. It is a pity, then, that the insertion of "human" into human rights has occurred so thoughtlessly and with such little attention to the prejudice of which this is an expression and to the extent to which this terminology may make future generations of beings like us hostages to fortune.

As Joseph Raz has commented recently, the "traditional approach" takes "human rights to be those important rights which are grounded in our humanity. ${ }^{5}$ The underlying thought is that the arguments which establish that a putative right-holder has a human right rely on no contingent fact except laws of nature, the nature of humanity and that the right holder is a human being. ${ }^{\prime 6}$ In an illuminating footnote Raz comments "One may allow that permanently comatose people do not have human rights. But one abandons the idea that human rights derive from our humanity once one says that babies or people with Down Syndrome do not have (certain) human rights." ${ }^{\prime 7}$ Raz goes on to advance a

Work on this paper was supported by the iSEI Wellcome Strategic Programme in The Human Body, Its Scope, Limits and Future. It reflects my collaboration with John Sulston on many of the themes here developed. I have also benefitted from comments by John Coggan, Sarah Chan, and Annabelle Lever on earlier drafts of this paper. 
positive account of human rights identifying them as those rights "regarding which sovereignty measures are morally justified" by which he means rights which "set limits to the sovereignty of states. ${ }^{\prime 8}$ However, Raz does not seriously consider nonhuman or partially human candidates for human rights however defined, ${ }^{9}$ and the question remains as to what or who are the rights holders over which limits are set to the sovereignty of states.

A deep question, and one begged by the traditional accounts of human rights just noted, is: What role does "humanity," species membership, being a human being, in short the descriptive sense of being human, play in our evaluative use of that term? When we identify humanity not simply with species membership, being a human being, but with being a moral being, we may be claiming one of two very different things. The first is that we humans, the species Homo sapiens sapiens, are characterized by, among other qualities, moral agency and other important features like the capacities for sympathy, empathy, and creativity. The second implies more: that the possession of these qualities is essentially human, possessed by us only because we are the species that we are. This second sense implies that our humanity in the moral sense is not simply species typical, but rather it requires being human in the biological or genetic sense. There is not only a danger, there is a long established and deeply ingrained habit and tradition of identifying properties or qualities that are contingently possessed by human beings as necessarily possessed by our kind and, moreover, necessarily not possessed by other kinds.

When we ask questions like "What is it to be human?" or talk about a person's "humanity" or talk of the "human spirit" or "human values," we not only emphasize the properties that typically distinguish our species from species not capable of having values but we indulge in a sort of chauvinism, celebrating our own kind as we do in a different sense when we talk of "Britishness," "European Culture," or "Western Civilization."10

This human chauvinism is often given a pseudo-scientific bent that is inimical to both the spirit of science and, indeed, to free inquiry. There is often talk of "species barriers"11 as if, insofar as such things exist, they are laws of nature set up not simply to protect our supposed species purity but to preserve those qualities we possess that may not only be currently particularly strongly represented in, or typical of, our species but may be unique to this planet. Of course, we should not lose these properties, but the question is whether we should improve upon them if we can. And a further important question, although one beyond the scope of this paper, is whether we should restrict these properties to our own species.

We do not want to lose our essential humanity if by that is meant those "human" characteristics that we value; but could we have not only those characteristics but also improve upon them if that is possible and add others that we do or would value to an equal or greater extent?

A number of recent developments in biotechnology and in our understanding of evolution indicate that the time has come not only for a reassessment of the role of "human" in human rights but of the idea of "humanity" in our conceptions of ourselves and of our place and our future in the universe. We will consider some of these before drawing some conclusions about the future of our species and the rights we have arrogated to ourselves. 


\section{Humanimals ${ }^{12}$}

Creatures with human and animal features are perennially fascinating. Two of the most familiar and frequently mentioned examples are centaurs and mermaids but there are many others, and science - fiction as well as fact - continues to provide new examples.

I prefer to use the term "humanimal" to cover any biological entities, whether individual creatures or cells, that have any mixture of animal and human elements.

Humanimals have been created for many years, and hybrids have almost certainly always existed naturally; however, the ethics of their creation and use is still in its infancy. A recent report by the United Kingdom Academy of Medical Sciences ${ }^{13}$ identifies many aspects of basic science that have been and continue to be studied in ways that involve the "mixing" of animal and human derived cells, in particular, "understanding the nature and potential of stem cells," most promising avenues of therapeutic and basic research that involves the study of the behavior of these cells in animal models, including, of course, human as well as animal derived stem cells. As the report notes, "[T]here are thousands of examples of transgenic animals, mostly mice, containing human DNA, mainly used as models of human gene function and human disease. ${ }^{\prime 15}$ The report notes that approaches "involving 'secondary' chimeras, i.e. the transfer of human cells into animals at a later stage of development, are already in widespread use in studies of human and mouse pluripotent and tissue-specific stem cells." ${ }^{16}$ It is also common practice to "investigate the potential of human neural stem cells to integrate appropriately into mouse or rat brain as a test of their potential safety and usefulness." ${ }^{\prime 17}$ Such interspecies humanimal research is widespread and is required not only for basic science but to develop and prove applications designed to treat serious human disease. As with all research, long-term and established benefits are necessarily in the future.

The ethical question is whether the sanctity of so-called species barriers or other objections to inter-species constructs affords good or even plausible reasons to abandon such research and forgo or postpone whatever benefits it might yield. The deeper theoretical and perhaps political question is whether interspecies creatures or enhanced human creatures created not by mixing matter from different species but by engineering further evolution or admixing or interfacing nonorganic technical elements with human biology might not only create better sorts of creatures but also whether such combinations have any necessary or for that matter contingent connection with the rights and responsibilities such creatures might have. Before further addressing this question we must remind ourselves of some assumptions and attitudes we have inherited.

\section{The Mermaid Myth}

It is important to distinguish between the creation of a human embryo incorporating animal material that will not be allowed to develop further and the possibility of bringing such an embryo to term so that it will become a living independent creature. In the case of the embryo, what will be created will simply be cells that will be maintained solely in vitro and will never be permitted to 
become human-animal hybrid or chimeric creatures. If, on the other hand, we are talking about the creation of fully formed mature hybrid creatures, then such a situation is clearly more dramatic and may involve different moral issues. ${ }^{18}$ However, here also we may be letting our expectations of what humanimal creatures would look like, and hence might be like, be conditioned by mythology, by what we might call the "mermaid myth," which involves the belief that if you mix the genes of a man and a fish you will necessarily make a creature with the recognizable features of both the progenitor creatures-you will make a mermaid, a creature that is half fish and half human.

\section{How Do We Identify Tissue or Genes as "Animal" or "Human"? 19}

From diet to vaccines, from drugs to xenotransplantation in its various forms, as Guiseppe Testa has noted: "[H]umans and animals have always been exchanging bits of their biological matter, intentionally or by chance, naturally or through artificial aids of various sorts. ${ }^{\prime 20}$ It is worth remembering that the majority of these encounters do not elicit particular fear or opposition. Diet is a good example: Except for vegetarians for whom objections are usually rooted in moral issues concerning animal welfare rather than species mixing, there does not seem to be any preoccupation with the entry of animal genes, cells, tissue, muscle, and other bodily products into our daily metabolism. ${ }^{21}$ However, we know, and we learn more almost on a daily basis, that diet influences our body at both genetic and epigenetic levels. "The effect of certain classes of nutrients on the methylation level of our DNA (one of the most meaningful types of epigenetic modification) is just the best defined example of the enduring effect of diet on our genetic networks, an effect that might even be passed on to future generations. ${ }^{\prime 22}$ In fact, if one were consistent in maximizing the purity of human matter, the only dietary choice would be cannibalism.

Vaccines and the various kinds of xenotransplantation are other, more visible, instances of animal-human mixing. Although whole organ xenotransplantations are still in very early experimental phases, porcine neural stem cells have been transplanted into a few patients, and millions of patients worldwide live with heart valves harvested from pigs or cows. In such cases, objections have tended to concentrate on specific dangers (e.g., the risk of transmitting animal viruses to the human population) rather than on a more general condemnation of humananimal mixing.

A typology of different sorts of human-animal mixing that has some utility is the following:

1) the daily crossing of species boundaries through diet, largely unnoticed and completely normalized in our culture;

2) the widespread use of animal products of various kinds as medical remedies, usually well accepted though with specific safety concerns, as in the various kinds of xenotransplantation;

3) the mixing of human and animal genes as proposed, albeit at a very limited level, in research;

4) the possibility of fully fledged hybrid or chimerical creatures mixing human and animal elements. 
The difference is then at the level of the "fundamental units" that get mixed in the four modalities: animal cells broken down to simple metabolites through the diet, cells that become parts of host tissues through xenotransplantation, and genes that mix up within the host cell in research or in the creation of humanimal creatures.

But is the sharp distinction between these different types of chimeras-and the equally sharp distinction in their moral evaluation-scientifically or ethically justified? The mixing of species is surely better understood as a continuum in which, as Testa notes, "the lines to be drawn between the acceptable and the nonacceptable do not align neatly with pre-existing biological categories (such as genes, cells, or metabolites) and the often inaccurate understandings that underlie them." 23

We need to reframe the notion of animal or human genes starting from the very problem of defining what it means to say that something is an animal or a human gene. For, in the light of the evolutionary conservation of many signaling pathways, "human" or "animal" gene can refer only to the fact that these sequences are sourced from a human or an animal. ${ }^{24}$ But from this it does not follow that an animal gene, once put into a human, behaves as an independent unit of "animal agency" or vice versa. And a clear reminder of this point comes from some of the most spectacular results of molecular biology in the 1990s.

In research in the mid-1990s, scientists defined the genetic hierarchy underlying the development of the eye. The experiment was spectacular: " a single gene, transplanted in tissues of the fly embryo such as the wings and the legs, was able to direct the formation of a whole eye, an ectopic eye. And yet, when the human homolog gene was transferred into a mouse to check for its ability to repair the small eye mutation, the result remained compelling: again, an eye was formed, testifying to the remarkable evolutionary conservation of genes and developmental pathways." ${ }^{\prime 25}$ However, the eye formed from a human gene, when inserted into the mouse, "forms" a mouse eye. Context, in other words, is just as essential as genes. ${ }^{26}$ This shows that genes that had their origin in one species may, when inserted in another species, express themselves in ways adapted to their context. When we mix the genes of different species we do not necessarily mix the characteristics of those species.

Mythology has not prepared us well for the advent of humanimals. Adding fish genes to human embryos is unlikely to give us mermaids, creatures with a woman's upper body and the tail of a fish; adding human genes to horse embryos will probably not create centaurs.

Is it too fanciful to suggest that it is the rooted and unreflective priority given to our species in, among other things, our conceptions of human rights and human dignity that are part of the problem here?

\section{Humans Are Already Humanimals}

We know we are descended from apes, but we perhaps need to remind ourselves that this descent is seamless and means that our genetic constitution contains a mixture of the genes of all the creatures, all the other species, that are part of the origin of our transient and transitional species.

In his essay "Gaps in the Mind" 27 Richard Dawkins asks us to imagine a contemporary woman holding her mother's hand on the coast of Africa. She holds her mother's hand, her mother holds her mother's, and so on. Each 
daughter is as much like her mother as daughters usually are. Each person takes up about a meter, a yard, of space as they hold hands back into the past. In just 300 miles (a small distance into Africa) the imaginary human chain reaches our common ape ancestor. We then need to imagine our ape ancestor holding by her other hand her other daughter and she hers and so on back to the coast. Again each daughter looks as much like her mother as mothers and daughters usually do. By the time the chain reaches back to the coast two contemporary females are looking at one another, each holding the hand of her mother, stretching in seamless connection back to a common ape ancestor. The two women, shall we call them, looking into each others' eyes are a modern human and a modern chimpanzee.

Dawkins' story reminds us of our ape ancestry and, most importantly, of the seamless transition between apes and humans. We need to bear in mind another lesson from evolution related to Dawkins' parable and outlined in his essay. That lesson is that it is an accident of evolution that ape species with whom (which?) we humans might have been able, successfully, to breed have not survived. So although the chimpanzee who shares a common ancestor with humans probably cannot breed with human beings (at least without technological assistance), there were certainly once nonhuman apes that, had they survived, could have been procreational partners for us, using "normal" sexual reproduction. To this extent, our ability to define ourselves as a species distinct from the other great apes is, in one of the most commonly used definitions of a species, namely, that its members are able to breed successfully with one another but not with other types of animals, an accident of history, not an immutable law.

The lesson of Dawkins' example most significant for our present discussion is that we humans are humanimals. We are creatures that are as we are because we result from a process-evolution-that has allowed us to evolve from our ape ancestors, not least by incorporating most of their genes and epigenetic features into our human constitution. In that we incorporate and retain these genes of animal origin we are indeed also humanimals, a species of interspecies creatures that many call "humans" but that are also, whatever else they are, humanimals. Although there may be no obvious point in Dawkins' chain where the mother was an ape and the daughter a human, some mothers (all mothers?) were apes whose daughters or grandchildren were more human than she was. For those who believe that humans are uniquely ensouled, some ape mother without a soul must have given birth to some daughter with a soul (unless souls also admit of degrees). For those who, like Francis Fukuyama, define "what it is to be human" in terms of a factor-factor $\mathrm{x}$ - that humans possess and nonhumans do not, there must have been a daughter with factor $x$ that her mother or great grandmother lacked. ${ }^{28}$ But in all of these cases, mothers and daughters must have been made of both human and animal elements (at least in the ways that those who object to the creation of humanimals find objectionable).

We should remember that Darwinian evolution is a random and purposeless process that, over millions of years, effects changes that benefit reproduction but not necessarily anything else-certainly not "fitness for purpose" defined in terms other than those that promote successful propagation of genes. 


\section{Brave New Worlds}

In Shakespeare's The Tempest, Miranda, brought up in the company of her father, Prospero (a magician), and assorted magical beings, sees ordinary men for the first time and likes what she sees:

\section{O wonder!}

How many goodly creatures are there here!

How beauteous mankind is, $\mathrm{O}$ brave new world that has such people in't. ${ }^{29}$

Since Aldous Huxley, brave new worlds have had a bad press, but Miranda is a better guide to the ethics of innovation than Aldous.

Miranda can be seen as celebrating the discovery of her own kind, a celebration of humanity, but I think she sees a deeper truth. The only "men" she has encountered hitherto (besides her father) are the magical intangible Ariel and the loathsome and pitiable Caliban-not much of a choice for a spirited young woman. When she encounters young, good-looking, Italian men, she is not so much confirming a species preference but demonstrating openness to a better world than the one she currently inhabits, a brave new world. Miranda's quotidian world is magical, and she chooses a better, less familiar world.

The prestige and power of science has sometimes been attributed to the fact that science is just "magic ... that works!" ${ }^{30}$ Insofar as it is, the future as well as the past is, and we may hope will continue to be, nothing short of magical and it will have all sorts of unprecedented and we may hope "goodly" creatures in't.

There are already, and in the future there will increasingly be, all kinds of new creatures out there, and it will be our business to ensure that they are all as "goodly" as they can be; some will be man-made (rather than man and woman made), resulting from something more akin to construction than sexual reproduction. They may result from synthetic gametes or so called synthetic biology, but, however synthetic their creation, they will be real in every important sense.

We have already considered humanimals; now we must consider brave new beings that continue the evolutionary process that has resulted in humans. Some will be enhanced humans, but others may be enhanced or at least altered animals. Other creatures will be mixtures, not of human and animal genes or parts, but perhaps humans with technology implanted (not like the heart pacemakers or prosthetic limbs with which we are familiar), perhaps with tiny "nanobots" that will dramatically enhance mental powers. Other possibilities include creatures that can literally interface with computers and access data and memory and information processing. Finally, increased longevity may eventually result in creatures that are effectively "immortal," an outcome that would certainly constitute a species change, because one way of defining humans is as "mortals" creatures that die, as opposed to immortals and Gods that, by hypothesis, do not. ${ }^{31}$

It is just as well that all these new sorts of beings are on the way, because, in the future, it is likely that we will have to face the end of humanity as we know it. We will either have died out altogether, killed off by self-created global warming or disease, or, we may hope, we will have been replaced by our successors produced by Darwinian evolution or, increasingly more likely, by the successors we have deliberately produced ourselves by what I have called "enhancement evolution." 
The end of humanity, then, is not in itself a concern; making sure that what replaces us is something better is a huge concern.

Because neither our planet nor our sun can endure forever, we will have, in the long term, also to face the necessity of finding a new habitat on another world or, indeed, of creating such a world.

\section{Synthetic Biology}

One of the most dramatic and important of the new technologies that will eventually produce new creatures is synthetic biology. When people talk about synthetic biology and synthetic life, they may have in mind Frankenstein scientists in the laboratory making creatures out of old socks and coat hangers or perhaps some bubbling vat of biochemical "primeval soup" out of which will arise either a monster or a perfect specimen of humanity. The creation of whole complex organisms to rival ourselves is certainly far in the future! Synthetic biology $^{32}$ is the name now used for a cluster of new technologies in which biomolecular components (natural or synthetic) are newly combined or reorganized in order to create novel genetic and biochemical circuitry, pathways, and, ultimately, organisms. It may be thought of as a hybrid discipline between science and engineering.

\section{Made in Our Image}

Synthetic biology has caught the imagination not least because it marks the beginnings of what looks like the possibility of manufacturing life forms from scratch and eventually of creating tailor-made creatures in our own image or, in principle, in the image and with the attributes of anything we like, or at least of anything we can engineer. This is heady stuff, and, if it works, may eventually give us unprecedented powers, which, like all powers, may be used for good or evil or simply wasted by lack of use. The storm of interest in synthetic biology has acted as a fascinating counterpoint to the ongoing discussion of the ethics and policy that should govern enhancing technologies of all sorts and human enhancement more generally. Such possibilities have forced us to reconsider who and what we are and to think more soberly and more objectively about the inevitability of change, including what will amount to further evolutionary change and, of course, change in our understanding of the nature and importance of human rights.

Is either synthetic biology or, indeed, the disappearance of humanity among the things we should be worried about? How should we begin to address such a question?

\section{Does Being Human Matter?}

Suppose our common ape ancestors in Africa had had the wit and foresight to get together with a simian agenda to block further evolution so that simian nature would have been preserved as "the common heritage of simian kind." ${ }^{\prime 33}$ If that had happened we would not be enjoying this pleasant discussion.

What matters, then, is not being human, but the existence of beings that have those powers and capacities, that have a nature that makes it worthwhile to be alive or to exist. 
Whether the new creatures are created by synthetic biology or by mixing the elements of different species or, indeed, through multiple forms of technology, we may, indeed, in all probability we must and we will, create new types of creatures that might join and, we may hope, will eventually replace us. Whether or not the nonhuman persons arise through technology or in the course of further Darwinian evolution, in the future, the far future perhaps, there will be no more humans. We do not need to worry about this so long as we are replaced by something better, by individuals better able to survive, flourish, be curious and inventive, and create a better world and an even better future for those who follow.

\section{Enhancements and Justice: Synthetic Sunshine}

The desire to better ourselves and make ourselves better is, as part of the curiosity and need that drives science, one of the oldest and most valuable of the things that characterize persons. An example of an enhancing technology already mentioned in this paper is synthetic biology, but it is instructive to consider another synthetic product of technology of somewhat more venerable antecedents, synthetic sunshine.

Enhancement technologies, ${ }^{34}$ including chemical, genetic, and other high-tech examples, have given and continue to give those who use them or can possess them an edge and have often been criticized for the injustice that this supposedly creates. However, before fires, candles, lamps, and other forms of man-made light, most people went to sleep when it got dark. Candles enabled social life and work (unsocial hours) ${ }^{35}$ to continue into and through the night and conferred all sorts of advantages on those able and willing to take advantage, to be sure, at the expense of those who could or did not take similar advantage.

Contemporary and future enhancements may create problems of injustice both in that they provide a means for some to gain an advantage (those who read by candlelight gain in a way that others do not) and because they may create unfair pressures as a result of the capabilities conferred by enhancement (like the pressure to stay up late and read or work because one can).

The solution is establishing "fair" working hours/working week and provision, at public expense if necessary, of sources of light-not banning the candles! The solution is a combination of regulation and distributive justice, not a Luddite rejection of technology.

Take a different but no less serious example: In the United Kingdom we are trying to make kidney transplants available to all who need them, as, it is believed, the Belgians, the Spanish, and the Austrians have managed to do. ${ }^{36}$ Even when that is achieved, we know that thousands in the rest of the world cannot obtain the transplants they need. We do not (and surely we should not) say that we will perform no more transplants here until the needs of all those in India can be met. And because we currently do not even have enough kidneys available for our own population, we do not think that fairness demands that we suspend our transplant program pending a sufficient supply for U.K. needs.

So when enhancements make life or lives better, they are justified if they do just that. If they also confer positional advantage, that is no part of the justification, and this fact will always create reasons to distribute such advantages as widely and fairly as possible. 


\section{Human Rights}

This brings us back to our starting point, with the relevance of humanity to human rights. As this essay on the nature of our humanity has, I hope, indicated, our humanity is both highly contingent and highly problematic. What the idea of human rights does, apart from some rather problematic self-congratulation for our particular stage of evolution and what we have done with it, is outline a set of entitlements for beings of a particular sort. These entitlements set limits, as Raz has argued, to the powers of the state, but they also set limits as to what individuals may do to one to another. The particular sorts of beings who have this species of important right are defined, or rather identified, in terms not of species membership or evolutionary stage, but in terms of a particularly interesting set of powers and capacities, certainly possessed by most humans at certain stages of their lives (species typically possessed, as it is sometimes said) but also possessed or at least possessable by other creatures. These characteristics I have defined and elaborated elsewhere. ${ }^{37}$ They can be seen as emblematic of the scientific endeavor, as characterized by relentless curiosity and the desire to find answers to questions that puzzle us; I prefer to see them in terms of a rather more abstract capacity to value existence. These capacities may well be unique in the universe and are, for all we know, unique to this planet. If creatures who can value themselves and can value others and can, in turn, claim respect are to continue, it may be vital both in the short and medium term for those creatures to further evolve. This may prove an essential precondition to an ability to better solve the problems that face us and will face our, hopefully improved, successors. And, in the long term, we may hope that those successors are the sort of creatures capable of finding other habitats elsewhere in the universe if self-conscious intelligent life of any sort is to continue.

To this end, fetishising humanity or humanness may be far from conducive to our interests as humans insofar as these extend to the existence and survival of our successors and the continuity of evolution.

The most urgent and worrying ethical problems surrounding the use of new technology, including synthetic biology, are not the dangers of pursuing such research and the innovation that may result. Such dangers attend all research and innovation of whatever nature and must always be resolved (if they are resolvable) by the best estimation of risk as against benefit. The dangers that have been consistently underestimated are the dangers of not pursuing such research because a host of feeble and often incoherent objections and objectors have placed themselves in the path of progress toward a better future for humanity and have been given unjustified respect. Turning our back on these possibilities perhaps because, in T.S. Eliot's words, ${ }^{38}$ we do not dare "disturb the universe" must not be an option. However, if we do have the courage and the good sense to disturb the universe, at least to the extent of trying to improve on the potentially disastrous vulnerabilities with which Darwinian evolution has left us, then we may indeed live to "hear the mermaids singing, each to each." Perhaps they may even sing to us.

\section{Notes}

1. Too universal because there are many humans to which it cannot and does not apply (see Harris J. The Value of Life. Routledge: London; 1985) and not universal enough for reasons also examined in 


\section{Taking the "Human" Out of Human Rights}

that book and, inter alia, in my Enhancing Evolution (Princeton, NJ: Princeton University Press; 2007).

2. And indeed the "dignity" out of human dignity. Analogous arguments show that the concept of human dignity is equally vacuous and redundant. See also R Macklin. Dignity is a useless concept. British Medical Journal 2003;327:1419-20.

3. See note 1, Harris 2007.

4. Greely H, Sahakian B, Harris J, Kessler RC, Gazzaniga M, Campbell P, Farah MJ. Towards responsible use of cognitive enhancing drugs by the healthy. Nature 2008;456:702-5.

5. For examples of this traditional approach see Nickel J. Making Sense on Human Rights. Oxford: Blackwell; 2006:38; Tasioulas J. The moral reality of human rights. In: Pogge T, ed. Freedom from Poverty as a Human Right. Oxford: Oxford University Press; 2007; Gewirth A. Human Rights: Essays on Justifications and Applications. Chicago: Chicago University Press; 1982:41; Jones P. Human Rights. In: Craig E, ed. The Routledge Encyclopaedia of Philosophy; available from http://www.rep. routledge.com/article/S105.

6. Raz J. Human rights without foundations; available from http://josephnraz.googlepages.com/ HumanRightswithoutFoundations.pdf (last accessed 15 Jan 2010. Forthcoming in Besson S, Tasioulis J, eds. Philosophy of International Law. New York: Oxford University Press.

7. See note 6, Raz 2009:3.

8. See note 6, Raz 2009:12 and 11, respectively.

9. Although Raz's account is consistent with the one developed in this paper.

10. Gandhi was once asked, allegedly by a reporter, what he thought of Western Civilization. He replied that he thought "it would be a very good thing." I believe this was after a tour of London, but I have been unable to find an authoritative source. See, e.g., http://en.wikiquote.org/wiki/Gandhi.

11. The idea of species barriers I have criticized in Harris J. Transhumanity: A moral vision of the twenty-first century. In: Davis NA, Keshen R, McMahan J, eds. Ethics and Humanity: Themes from the Philosophy of Jonathan Glover. New York: Oxford University Press; 2009.

12. In this section, I borrow from my "Transhumanity: A moral vision of the twenty-first century"; see note 11 .

13. Academy of Medical Sciences. Inter-Species Embryos: A Report by The Academy of Medical Sciences 2007; available at http://www.acmedsci.ac.uk/p99.html. The present author acknowledges his coauthorship of this report and thanks fellow members of the Academy Working Group for many useful insights.

14. See note 13, Academy of Medical Sciences 2007:3, 33.

15. See note 13, Academy of Medical Sciences 2007:3, 33.

16. See note 13, Academy of Medical Sciences 2007:34.

17. See note 13, Academy of Medical Sciences 2007:34. See Linvall O, Kokala Z. Stem cells for the treatment of neurological disorders. Nature 2006;441:1094-6.

18. I use here words also used in "Inter-species embryos"; see note 13, Academy of Medical Sciences 2007.

19. In this section I have, with his permission, borrowed extensively from the work of my friend and colleague Giuseppe Testa. We have worked together on the ethics of humanimals, but this section on context belongs to Giuseppe. I do not quote him verbatim because I draw these sections from an unpublished paper we authored together.

20. Hyun I, Taylor P, Testa G, Dickens B, Jung KW, McNab A, et al. Ethical standards for human-toanimal chimera experiments in stem cell research. Cell Stem Cell 2007;1:159-163 at p. 159.

21. It is true that humans are less sanguine about being eaten by other organic creatures than they are about eating them, but either way we end up with humanimals.

22. See note 20, Hyun et al. 2007:159.

23. See note 20, Hyun et al. 2007:159.

24. See note 20, Hyun et al. 2007:160.

25. See note 20, Hyun et al. 2007:160.

26. Halder G, Callaerts P, Gehring WJ. Induction of ectopic eyes by targeted expression of the eyeless gene in Drosophila. Science 1995;267:1788-92; Oliver G, Gruss P. Current views of eye development. Trends in Neuroscience 1997;20:415-21; Quiring R, Walldorf U, Kloter U, Gehring WJ. Hormology of the eyeless gene of Drosophila to the Small eye gene in mice and Anividia in humans. Science 1994;265:785-9.

27. In Dawkins R. The Devil's Chaplain. London: Phoenix; 2004:23-31. I use the summary of Dawkins that appears in my Enhancing Evolution; see note 1. I apologize for my frequent recourse to this wonderful example. 


\section{John Harris}

28. See Fukuyama F. Our Posthuman Future. London: Profile Books; 2002:160.

29. Shakespeare W. The Tempest. Act 5. Scene 1.

30. An epigram that came to me via Frank Cioffi, my undergraduate philosophy tutor in 1966. I don't know where he found it, but Internet sources suggest that Kurt Vonnegut may have borrowed it from him or vice versa.

31. Harris J. Intimations of immortality. Science 2000;288:59; Harris J. Intimations of immortality: The ethics and justice of life extending therapies. In: Freeman M, ed. Current Legal Problems. Oxford: Oxford University Press; 2002:65-97.

32. In describing synthetic biology, I draw heavily on the ideas and research of my colleague John McCarthy, Director of the Manchester Interdisciplinary Biocentre, University of Manchester.

33. To lightly adapt The Universal Declaration on the Human Genome and Human Rights published by UNESCO as a pamphlet December 3, 1997, which absurdly endorses "[t]he preservation of the human genome as common heritage of humanity."

34. For a detailed defense see note 1 , Harris 2007, on which book I draw in this section. See also note 4 , Greely et al. 2008.

35. It is perhaps another irony that unsocial hours are parasitic upon the concept of social hours, themselves the by-product of the leisure that technology has facilitated.

36. Statistics from Eurotransplant seem to suggest that waiting lists do still exist in Belgium and Austria (Eurotransplant does not extend to Spain), although they may be greatly reduced.

37. See note 2, Harris 1985; Harris J. The concept of the Person and the value of life. Kennedy Institute of Ethics Journal 1999;9:293-308.

38. Eliot TS. The love song of J. Alfred Prufrock. T.S. Eliot Collected Poems. London: Faber and Faber; 1963. 